\title{
Counseling and Assistance in Making Ovitrap with the Principle of Re- use To control Aedes aegypti larvae
}

\author{
Ratna Dian Kurniawatia), and Agung Sutriyawan \\ Public Health Study Program, Faculty of Health Sciences, Bhakti Kencana University, Tasikmalaya, \\ Indonesia \\ a)Corresponding author: ratna.dian@bku.ac.id
}

\begin{abstract}
Dengue hemorrhagic fever (DHF) is still a health problem, especially in endemic areas. Aedes aegypti mosquito as a vector for the dengue virus needs serious attention. The $3 \mathrm{M}$ Plus Mosquito Nest Eradication has been promoted by the government as a preventive effort to increase the incidence of dengue fever. The purpose of this community service is to increase the knowledge of housewives (IRT) through the implementation of counseling and assistance in making ovitrap with the principle of reuse to reduce the population of Aedes aegypti larvae. This community service was carried out with an intervention approach in a one group pretest-posttest design experimental design. The location of community service is in RW 04, Cisaranteun Endah Village at 199 IRT. Most of the IRT (53.3\%) before attending the counseling had less knowledge and after attending the counseling most of the IRT (69.3\%) had good knowledge. The average score before counseling was 50.28 with a standard deviation of 15.518 and the average score after counseling was 81.08 with a standard deviation of 10.325 , and the p-value was 0.000 . This means that there is a significant difference in the level of knowledge of IRT before and after being given counseling and assistance. The goal of community service is to achieve a significant increase in IRT knowledge about ovitrap as a means of controlling the population of Aedes aegyti mosquito larvae, how to make it and provide assistance in making ovitrap with the principle of Re-use.
\end{abstract}

Keywords: Ovitrap making, Re-use, dengue control, Aedes aegypti larvae

\section{INTRODUCTION}

Dengue Hemorrhagic Fever (DHF) is a disease caused by the dengue virus. Dengue Hemorrhagic Fever (DHF) is commonly found in areas with tropical climates and is often endemic to certain populations or regions. Dengue Hemorrhagic Fever (DHF) is transmitted by Ae. aegyti that can grow rapidly along with population growth. The reproduction of Ae. aegyti is increasing, especially in the rainy season. Indonesia, with its rainy season, has several dengue endemic areas that need serious attention in preventing and controlling the increasing incidence of dengue.

Based on WHO data in the African Region, namely in Burkina Faso, the dengue fever outbreak reached 1061 cases. A significant decrease in 2017 in America, from 3,177,171 cases in 2016 to 584,263 cases. Panama, Peru and Aruba are the countries whose cases increased during 2017(WHO, 2018). Cases in Indonesia in 2018 amounted to 65,602 cases, with a death toll of 467 people. In 2017 there were 68,407 cases with a death rate of 493 people. The DHF morbidity rate in 2018 decreased compared to 2017, from 26.10 to 24.75 per 100,000 population. The decrease in the case fatality rate (CFR) from the previous year was not too high, namely $0.72 \%$ in 2017, to $0.71 \%$ in 2018 (Ministry of Health RI, 2018). The West Java DHF case ranks 26th with 17.94 per 100,000 population, meaning that it still has a high DHF morbidity rate (Kemenkes RI, 2018). DHF cases in Bandung have increased from 1,786 cases in 2017 to 2,826 cases in 2018. The five-year cycle is an indicator of a significant increase in the number of DHF cases and 2018 is the peak of that cycle. Data from the Bandung City Health Office, there were 1,629 cases of dengue fever from January to May 2020. In January there were 248 cases, in February 330, March 479 cases, April 385 cases, and May 187 cases (Yudatama, 2020). In 2018 at the Rusunawa Health Center there were 95 cases and in 2019 there were 241 cases. Efforts 
to control DHF have been carried out through PSN 3M Plus counseling and periodic larva monitoring which is an indicator of DHF control, namely the larva-free rate (ABJ). ABJ's achievement has not met the government's target of 76.94\% and in 2019 86.53\% (anonymous, 2019)

The 3M Plus Mosquito Nest Eradication (PSN) is an effort to prevent dengue hemorrhagic fever (DHF). The Directorate General of PPM-PLP of the Indonesian Ministry of Health has stated that PSN 3M Plus is the most effective and appropriate way to prevent and eradicate DHF through the participation of all levels of society (Kurniawati, 2020). The use of ovitrap as an application in the sense of the word Plus in the 3M Plus Mosquito Nest Eradication needs attention. Ovitrap is a tool used to modify the environment, namely at the place where mosquitoes lay eggs or breading place, where this ovitrap functions as a mosquito trap that can break the cycle of mosquito development. Ovitrap is well-known among researchers as an effort to control mosquito larvae and in some areas there are already people mobilizing their communities, although not yet massively.

Research that has been done by Hidayati, states that Ae. aegyti is found inside the house and Ae. albopictus outdoors. The number of eggs obtained from ovitraps inside the house was 3 times more than eggs from ovitraps outside the home in Sukabumi City (1307 vs 429). Ovitrap index at home reached $60 \%$, or 1.6 times higher than the ovitrap index outside the home (37\%) in 14 urban villages in Sukabumi City. The condition of the house with poor ventilation and sanitation has a risk of 3.09 times to increase the ovitrap index number (high density of Aedes sp.). Based on the results of this study, it can be said that the ovitrap used is effective for trapping mosquitoes and can reduce mosquito density (Hidayati, Lisa; Hadi, Upik Kesumawati; Soviana, 2017).

Ratna's previous research became the basis for the implementation of this community service. The results of Ratna's research stated that most housewives (IRT) had less knowledge, but had high motivation in using ovitrap as an effort to control Aedes aegypty mosquito larvae. High motivation from IRT can be caused by IRT seeing the economic benefits of using Ovitrap which is easy, cheap and safe. High motivation in using ovitrap is an indicator that housewives will prefer to use ovitrap if only housewives know clearly what ovitrap is, the purpose, benefits and how to use ovitrap. So here is an opportunity to increase the use of ovitrap by IRT in controlling Ae. aegypti. Ovitrap is economically very cheap, easy to make, easy to practice and effective in reducing the population of Aedes aegypty mosquito larvae. The high motivation of housewives can be the basis for activating the role of housewives as agents of change in family health which can be a determining factor for the success of the 3M Plus PSN program through the use of ovitrap to reduce the population of Aedes spp mosquito larvae. Ratna suggested the need to increase knowledge through socialization of the manufacture and use of Ovitrap (Kurniawati, Ratna Dian; Sutriyawan \& Rahmawati, 2020).

Based on the above background, the authors are interested in doing community service aimed at increasing IRT knowledge through the implementation of counseling and assistance in making ovitrap with the principle of Re-use to reduce the population of Ae. aegypti larvae.

\section{METHOD}

This type of community service is analytic with a one group pretest-posttest design. The location of this community service is RW 04, Cisaranteun Endah Village, Arcamanik District, which was carried out in 3 stages on 26 and 30 September 2020 and 10 October 2020 via the google meet application, totaling 199 IRT. The participants of this community service were IRT who were the samples in Ratna's previous research who were willing to take part in research and community service activities as a whole. This community service uses self-funding.

The procedure starts after the author gets a community service permit. Respondents who have been determined in accordance with the inclusion criteria above. The author explains the intent and purpose of this community service to IRT who have gathered at google-meet. After the IRT was ready, the knowledge questionnaire as a pre-test was distributed in the form of a google-form link. After the IRT finished filling out the google-form, the event continued with 
counseling about ovitrap as a means of controlling the population of Ae. aegyti, how to make it and provide assistance in making ovitrap with the principle of Re-use using used goods, namely from used mineral water bottles and used plastic. The intervention was carried out 2 more times through the same media, namely a power point about ovitrap and a video on making ovitrap. The intervention carried out in 3 stages for 2 weeks is expected to increase IRT knowledge about ovitrap, how to make and use it. It is hoped that if knowledge increases, it will be a stimulus for lasting behavioral changes in the use of ovitrap as a population controller for Aedes aegyti mosquito larvae. In the 3rd stage of the intervention, the authors spread the google-form link as a post test and then the authors carried out the measurement and data processing process using the editing, coding and data entry stages. Normality test using KolmogorovSmirnov test. The data analysis technique used is the $t$ test statistical test. The difference between pretest and posttest is assumed to be the effect of treatment or experiment. The statistical test used was paired t test (paired) dependent sample (not independent).

\section{RESULTS}

Community service carried out is counseling and assistance in making ovitrap. Counseling and mentoring are carried out in 3 stages on 26 and 30 September 2020 and 10 October 2020 via the google meet application. This community service activity aims to increase the knowledge of IRT in carrying out counseling and assistance in making Re-use principle ovitrap to control the population of Aedes aegypti larvae.

Based on the results of community service that has been carried out, it is found that most of the IRT (71.9\%) do not work, almost all respondents $(79.9 \%)$ have a high school education (SMA). Most of the IRT (53.3\%) before attending the counseling had less knowledge and after attending the counseling most of the IRT (69.3\%) had good knowledge.

The results of the knowledge data before and after the distribution analysis. Data testing was carried out using the Kolmogorov Smirnov normality test, because the sample size was $>50$ IRT. The results of the normality test of the two variables tested showed that the data were not normally distributed, so the test used was the Wilcoxon test to obtain different test results from the interventions that had been carried out.

The average score before being given counseling was 50.28 with a standard deviation of 15.518 and at the time after being given counseling the average score was 81.08 with a standard deviation of 10.325 , and the p-value obtained was 0.000 . This means that there is a difference in the level of knowledge of IRT before and after being given counseling and assistance in other words there is a significant difference after intervention in the form of counseling and mentoring is carried out.

\section{DISCUSSION}

Knowledge is a predisposing factor that plays a very important role in the concept of behavior change by Green in Notoatmojo (Notoatmodjo, 2014). Knowledge is the basic thing that shapes a person's experience and becomes a stimulus for behavior change. According to Plumer's Theory in Ratna, knowledge is a factor that influences participation. A person's knowledge will affect the entire community environment. This makes the public understand whether or not the stages and forms of participation / participation exist (Dian Kurniawati, Ratna; Murni Saleha, 2018). This is what the author tries to touch in the implementation of this community service. The counseling and assistance carried out can be a stimulus for behavior change so that IRTs have a comprehensive level of knowledge which in turn encourages IRTs to apply Ovitrap as an effective, easy, inexpensive and safe method for health and the environment. Socialization or counseling as an effort to increase the knowledge of housewives regarding the use of ovitrap as an effort to control the larval population of Ae. aegypti. Good family knowledge can provide effective prevention of the incidence of dengue hemorrhagic 
fever so that it can reduce the incidence and improve the health status of the family (Ernyasih, 2019).

In fact, ovitrap has not been socialized thoroughly and massively so that its benefits have not been felt by the wider community. Whereas various studies have proven the effectiveness of ovitrap in controlling mosquito larvae populations, especially Ae. aegyti which can cause DHF. One of the results of research on the effectiveness of ovitrap was carried out by Pujiyanti. The results showed that the application of the tool was able to increase the larva free rate, but the application of ovitrap could not be separated from the implementation of PSN in every family. PSN application with lethal ovitrap in the intervention area resulted in an increase in ABJ value of $46.15 \%$, while PSN application with non-lethal ovitrap in the control area resulted in an increase in ABJ value of $3.12 \%$. Pujiyanti even suggested that the community should accept the use of PSN 3M plus a combination of lethal ovitrap in the field but need to be equipped with the correct way of making and using it. PSN socialization or counseling is needed simultaneously and thoroughly before the lethal ovitrap tool is applied in the field (Pujiyanti, 2019). This is in accordance with Anggraini's research, namely prevention and eradication measures are more effective by eradicating larval sources through PSN (Anggraini, 2016).

The community service that has been carried out carries a double mission on the theme of Re-use, namely the reuse of used goods, in this case, used mineral water bottles wrapped in black used crackle plastic. In its multiple mission, it is inspired by the PSN 3M Plus, namely the Recycling with Re-use Principles section. Basically the community service that has been carried out carries a double mission on the theme of Re-use, namely the reuse of used goods, in this case, used mineral water bottles wrapped in black used crackle plastic. In its dual mission, it is inspired by PSN 3M Plus, namely the Recycling with Re-use Principle section. Basically, unused used goods that have the potential to hold water must be managed with the $3 R$ principle (Reduce, Re-use, Recycle). Used goods that can hold water will be a risk factor for breeding Ae. aegyti. This is in accordance with Ratna's research which states that most $(61.1 \%)$ heads of families in Margaasih Village recycle used goods. And there is a significant relationship between recycling used goods and the incidence of dengue fever with a p-value of 0.02. (Kurniawati, 2020). In line with Ratna's research, used goods that are left scattered can collect water and create puddles, so that in the puddles Ae. aegypti will lay eggs and breed. Habitat and breeding places of Ae. aegypti requires clear water that is not grounded directly on the ground, such as jars, buckets, drums, and used goods that hold water (Awaluddin, 2017).

\section{CONCLUSIONS AND RECOMMENDATIONS}

Community service, both counseling and assistance in making ovitrap can be carried out smoothly. The goal of community service activities was achieved, namely a significant increase in IRT knowledge about ovitrap as a means of controlling the population of Ae. aegyti, how to make it and provide assistance in making ovitrap with the principle of Re-use. The increase in knowledge can be seen from the results of the Wilcoxon test with a p-value of 0.000 .

There is a need for continuous efforts in the application of ovitrap through cross-sectoral collaboration from the Puskesmas and the local government, in this case, through the Empowerment of Family Welfare (PKK), the Taklim Council or Non-Governmental Organizations to always make continuous improvements in the implementation of PSN 3M Plus with the use of ovitrap.

\section{ACKNOWLEDGMENTS}

The authors thank IRT RW 04, especially RT 1-3 Cingised, Cisaranteun Endah Village, Arcamanik District, Bandung City, Head of RW 04, and the research team. To the Faculty of Health Sciences who have given permission to carry out this research. To all those who have helped so that the implementation of this community service can be carried out properly 


\section{REFERENCES}

Anggraini, A. (2016). Pengaruh Kondisi Sanitasi Lingkungan Dan Perilaku 3m Plus Terhadap Kejadian Demam Berdarah Dengue Di Kecamatan Purwoharjo Kabupaten Banyuwangi. Jurnal Pendidikan Geografi, Volume 03(2016), 321-328. Retrieved from https://jurnalmahasiswa.unesa.ac.id/index.php/swara-bhumi/article/view/16911/15367

anonim. (2019). Laporan Tahunan PKM Rusunawa. Bandung.

Awaluddin. (2017). Koreasi Pengetahuan dan Sikap Keluarga Terhadap Tindakan Pencegahan Deman Berdarah Dengue. Jurnal Endurance, 1(2), 263-269.

Dian Kurniawati, Ratna; Murni Saleha, A. (2018). Faktor-Faktor Yang Berhubungan Dengan Keikutsertaan Masyarakat Dalam Kegiatan Pemicuan Stop Buang Air Besar Sembarangan Di Desa Ciaro Wilayah Kerja Puskesmas Nagreg Kabupaten Bandung. Bandung.

Ernyasih. (2019). Hubungan Karakteristik Responden, Pengetahuan dan Sikap Kepala Keluarga terhadap Praktik Pencegahan Demam Berdarah Dengue (DBD). Jurnal IImu Kesehatan Masyarakat, Vol. 08, N(Maret 2019), 6-13. Retrieved from http://journals.stikim.ac.id/index.php/jikm/article/view/203

Hidayati, Lisa; Hadi, Upik Kesumawati; Soviana, S. (2017). Ae. aegypti ditemukan di dalam rumah dan Ae. albopictus di luar rumah. Jumlah telur yang diperoleh dari ovitrap di dalam rumah 3 kali lebih banyak dibandingkan dengan telur dari ovitrap di luar rumah di Kota Sukabumi (1307 banding 429). Indeks ovitrap di. Jurnal Entomologi Indonesia Indonesian Journal of Entomology, 14 No. 3(November 2017), 126-134. https://doi.org/DOI: 10.5994/jei.14.3.126

Kemenkes RI. (2018). Profil Kesehatan RI 2017. Jakarta: Kementerian Kesehatan Indoneisa.

Kurniawati, Ratna Dian; Sutriyawan, A., \& Rahmawati, S. R. (2020). Analisis Pengetahuan dan Motivasi Pemakaian Ovitrap Sebagai Upaya Pengendalian Jentik Nyamuk Aedes Aegepty. Jurnal Kesehatan Masyarakat, https://doi.org/https://doi.org/10.33221/jikm.v9i04.813

Kurniawati, R. D. E. (2020). Analisis 3M PLUS Sebagai Upaya Pencegahan Penularan Demam Berdarah Dengue Di Wilayah Puskesmas Margaasih Kabupaten Bandung. Vektora: Jurnal Vektor Dan Reservoir Penyakit, Vol 12 No(2020-07-30), 1-10. Retrieved from https://ejournal2.litbang.kemkes.go.id/index.php/vk/article/view/1813

Notoatmodjo, S. (2014). IImu Perilaku Kesehatan. Jakarta: Rineka Cipta.

Pujiyanti, A. (2019). Uji Coba Efektivitas Lethal Ovitrap Untuk Pengendalian Vektor Demam Berdarah Dengue Di Kota Salatiga. Salatiga.

WHO. (2018). Dengue and severe dengue. World Health Organization, (September 2018), 2-7.

Yudatama, S. (2020). Belum Usai dengan Covid-19, Kota Bandung Kini Hadapi Endemik DBD, Dinkes: Terdapat 1.629 Kasus. Bandung. Retrieved from https://www.pikiranrakyat.com/bandung-raya/pr-01401049/belum-usai-dengan-covid-19-kota-bandung-kinihadapi-endemik-dbd-dinkes-terdapat-1629-kasus 


\section{APPENDIX}

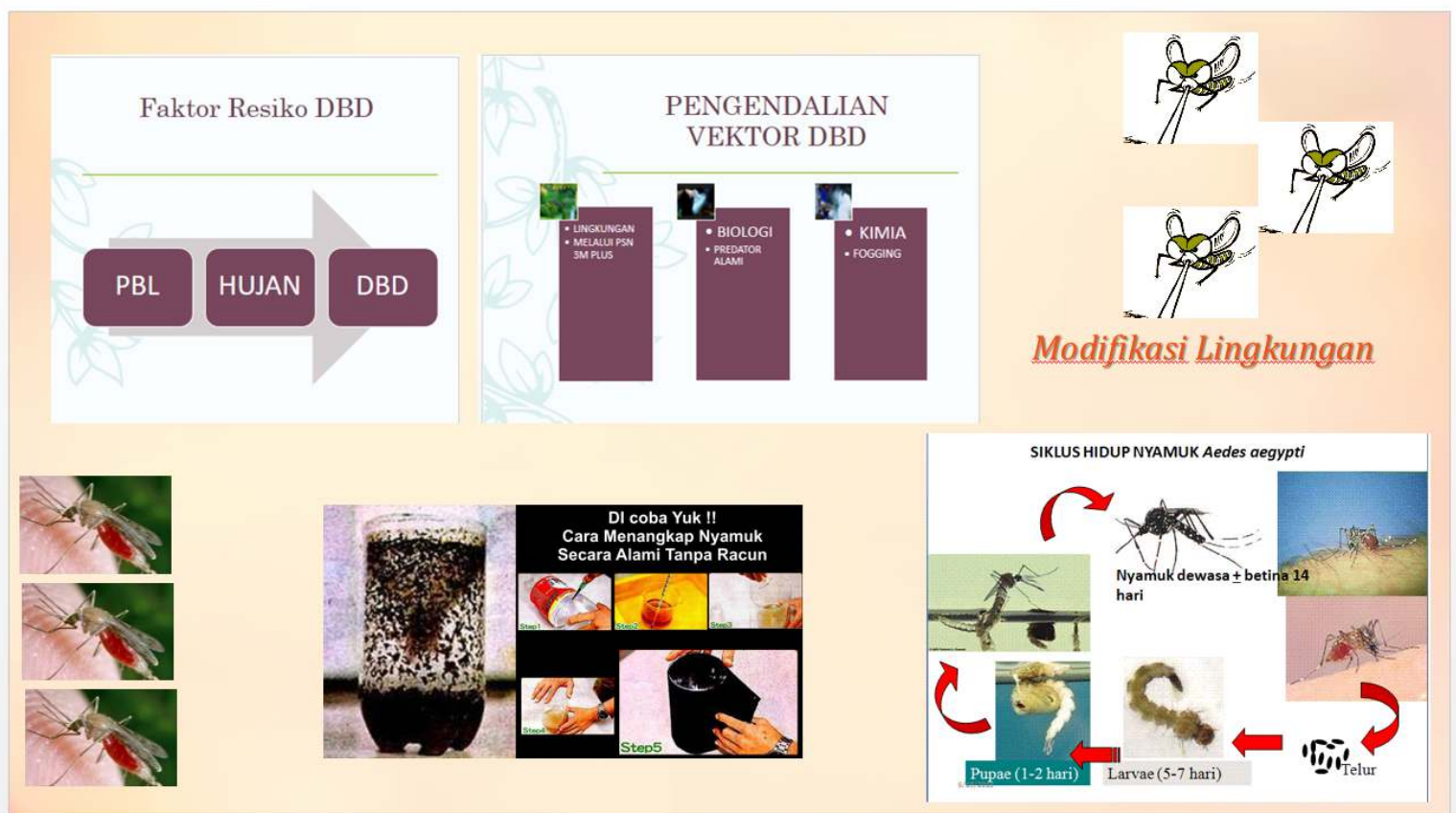

Figure 1. Documentation of Community Service by ppt Counseling Ovitrap
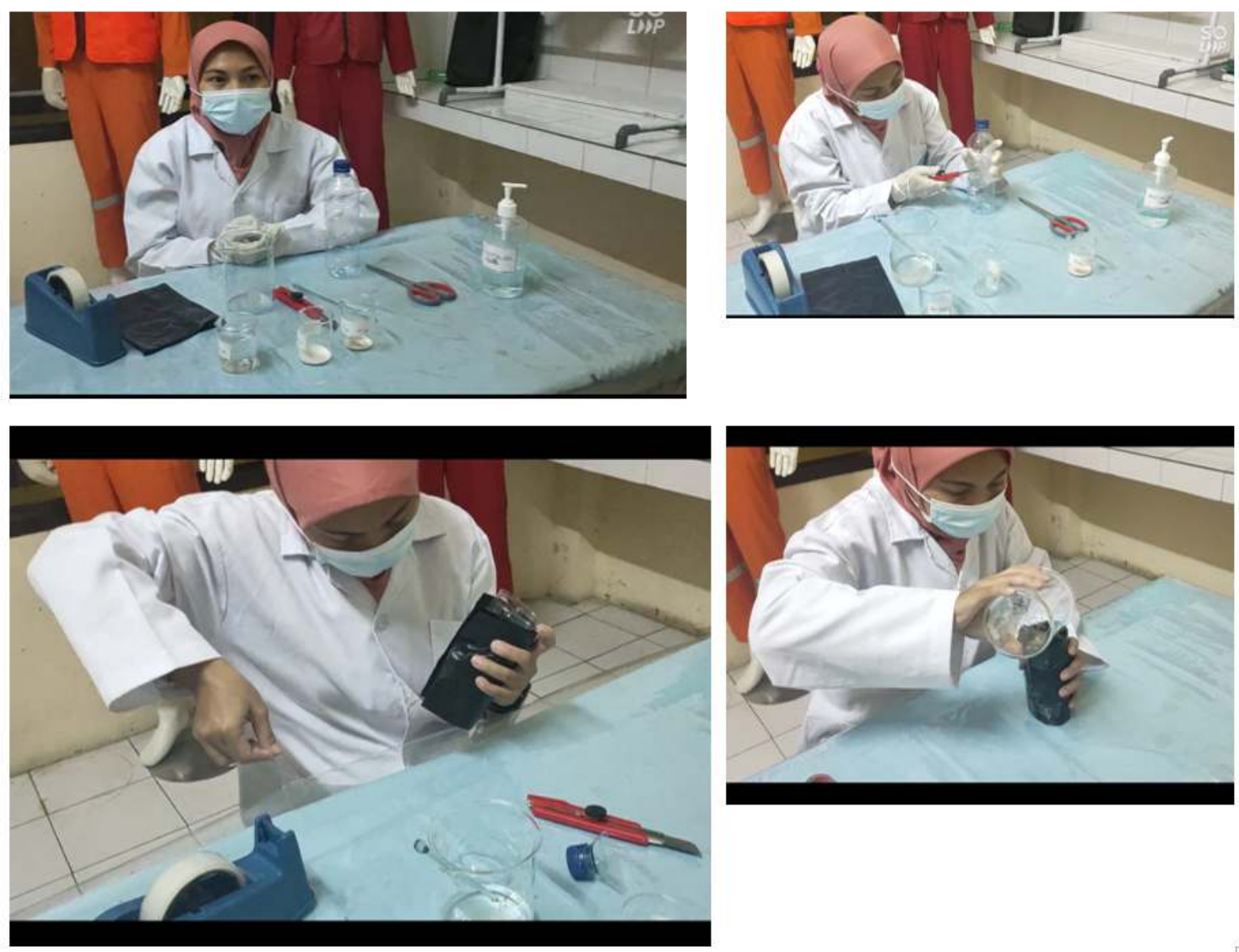

Figure 2. Demonstration Documentation through Video Making Ovitrap 